\title{
УДК 378.147:811.112.2’342(045) \\ ПРИЧИНИ, ПРОФІЛАКТИКА Й КОРЕКЦІЯ ФОНЕТИЧНИХ ПОМИЛОК У ВСТУПНОМУ КОРЕКТИВНОМУ КУРСІ
}

\author{
Гутник В. М. \\ abcdefg27@ukr.net \\ Київський національний лінгвістичний університет \\ Дата надходження 17.04.2018. Рекомендовано до друку 28.05.2018.
}

\begin{abstract}
Анотація. У статті визначено й описано причини виникнення фонетичних помилок. Авторкою проаналізовано вплив фільтру рідної мови на формування фонетичних навичок як складової фонетичної компетентності. Розкрито явище фосилізації та його негативний вплив на процес формування фонетичної компетентності. Запропоновано способи запобігання проявам фосилізації. У статті викладено розроблену авторкою методику корекції ненормативних деформованих фонетичних навичок. Сформульовано вимоги до сучасного фонетичного курсу й охарактеризовано його особливості, які ускладнюють формування фонетичної компетентності на початковому ступені навчання й вивчення іноземних мов.

Ключові слова: фонетична компетентність, фонетичні помилки, фільтр рідної мови, фосилізація, вступний корективний курс, корекція помилок
\end{abstract}

Гутник В. М. Киевский национальный лингвистический университет Причины, профилактика и коррекция фонетических ошибок в вводном коррективном курсе В статье определены и описаны причины возникновения фонетических ошибок. Проанализировано влияние фильтра родного языка на формирование фонетических навыков как составляющих фонетической компетентности. Раскрыто явление фоссилизации и его негативное влияние на процесс формирования фонетической компетентности. Предложены способы профилактики фоссилизации. В статье предлагается разработанная автором методика коррекции ненормативних деформированных фонетических навыков и профилактики. Сформулированы требования к современному фонетическому курсу и охарактеризованы его особенности, усложняющие формирование фонетической компетентности на начальном этапе обучения и изучения иностранного языка.

Ключевые слова: фонетическая компетентность, фонетичекие ошибки, фильтр родного языка, фоссилизация, вводный коррективный курс, коррекция ошибок.

Gutnik V. Kyiv National Linguistic University

Causes, prevention and correction of phonetic mistakes in the introductory corrective course

Abstract. Introduction. Mistakes and their correction are inevitable in a teaching process. Phonetic mistakes are especially challenging, as the student is unable to correct them on his own. As of today, the problem of correcting phonetic mistakes at the beginner level has not been given sufficient consideration. Purpose. Our focus is on the introductory corrective course, whose purpose is to form phonetic competence as part of the general communicative competence involving a foreign language. Methods. This articleincludes several objectives: describing the nature of phonetic mistakes, exploring the factors leading to their appearance,figuring out ways of their correction, identifying ways of their prevention. Our research is based on the results of the testing of 289 students from seven Ukrainian colleges during the years of 2007-2011. The students were tested before the start of the introductory corrective course. More testing was administered upon the completion of the latter, and this time, 291 students were included. During the years of 2013-2017, we asked 87 students from the Kiev National Linguistic University to share their opinions on how pronunciation was supposed to be taught in grade and high school. In 2018, we questioned 33 students from the Kiev National Linguistic University on the issue of correcting phonetic mistakes made by students in grade and high school. The students 'answers were carefully reviewed, interpreted and highlighted in the subsequent article. Results. The study of the process of forming communicative competence at the beginner level of studying German, the analysis of students' learning experiences, as well as their psychological and emotional responses to teacher's corrections helped us to come up with a series of specific exercises. The latter serve as the foundation for the method of forming communicative competence offered by us. We came up with a communication oriented introductory 
Гутник В. М. Причини, профілактика й корекція фонетичних помилок у вступному корективному курсі

corrective course that includes exercises geared toward relevant and timely correction of phonetic mistakes, as well as their prevention. Of special importance are three- and five-step complex exercises. Students are encouraged to formulate phonetic rules themselves, which helps them to develop the knowledge of phonology and to prevent phonetic mistakes. Conclusion. The proposed study is a step towards understanding the nature of phonetic mistakes and discovering ways of their prevention.

Keywords: Phonetic competence, phonetic mistakes, first language filter, fossilization, introductory corrective course, correction of mistakes.

Постановка проблеми. Інтеграція України до європейського освітнього простору зумовлює необхідність досконалого володіння іноземними мовами (IM). Особливого значення в усному спілкуванні набуває фонетичний аспект - своєрідна “звукова візитка". За вимовою можна визначити рівень освіти людини, їі соціальний стан і навіть деякі риси іï характеру (Dieling, Hirschfeld, 2000). Ненормативна вимова може спричинити не тільки труднощі під час комунікації (вимушені повторення запитання чи репліки), а й небажання спілкуватись 3 фонетично некомпетентним мовцем, який припускається помилок.

Помилки та їх корекція вважаються невід'ємними елементами процесу навчання й вивчення IM і є “каменем спотикання” як для тих, хто вивчає мову, так і для викладачів, які керують освітнім процесом. Багаторічний практичний досвід викладання IM, зокрема німецької мови, дає змогу стверджувати, що кожен, хто вивчає німецьку мову як іноземну, в процесі навчання припускається помилок. Попри всі зусилля викладача утримати студента “на правильному шляху” помилки супроводжують мовленнєвий процес, насамперед його фонетичне оформлення.

Аналіз останніх досліджень і публікацій. Природа, причини й корекція помилок були предметом багатьох грунтовних досліджень: зокрема Н. М. Кондакова розробила методику попередження помилок в іншомовному писемному мовленні (2006), Н. О. Ларіна проаналізувала дидактичні функції помилок (2005), К. Клеппін визначила місце помилок у процесі навчання та запропонувала способи їх корекції як в усному, так і в писемному мовленні (1998), Г. В. Ейгер описав механізми контролю правильності висловлювання (1990), Х. Раабе обгрунтував теорію помилок у процесі оволодіння німецькою мовою як іноземною (1980), Х. Рамге охарактеризував мовні помилки й запропонував прийоми їх корекції (1980).

Значний інтерес представляють роботи, в яких розглядаються природа, причини, типи й корекція фонетичних помилок. Проте їхня кількість є надзвичайно обмеженою. К. Бьотгер пропонує аналіз частотних фонетичних помилок, порівнюючи російську й німецьку мови (2008), Г. Ліст зосереджує свою увагу на помилках під час сприйняття мовлення на слух (1980).

Слід наголосити на тому, що особливості роботи з фонетичними помилками на початковому ступені навчання й вивчення IM, а саме у вступному корективному курсі (ВКК), який традиційно проводиться у мовних закладах вищої освіти (3ВО), залишилась поза увагою науковців. Є очевидним, що саме у ВКК формуються основи фонетичної компетентності (ФК) як складника іншомовної комунікативної компетентності (ІКК). Отже, значення такого курсу важко переоцінити.

3 огляду на викладене вище, мета статті полягає у дослідженні сутності мовних помилок, зокрема фонетичних, визначенні причин їх виникнення, розробленні методики їх корекції й прийомів профілактики їх прояву.

Основні результати дослідження. Багаторічний досвід організації й проведення ВКК змушує нас і дає право констатувати, що більшість випускників закладів середньої освіти (3СО), вступаючи до ЗВО, не володіють всупереч Програмним вимогам (Освітня програма, 2017) нормативними фонетичними навичками й необхідним мінімумом фонетичних знань.

Згідно з навчальною Програмою (Освітня програма, 2017) випускники ЗСО мають знати особливості звукового складу німецької мови та його реалізації в усному мовленні. На першому занятті з німецької мови у ЗВО ми спостерігаємо протилежне: більшість першокурсників не мають уявлення про фонетичні закономірності, які існують в усному німецькому мовленні 
чи читанні вголос; найбільшою проблемою $є$ нездатність розрізняти довготу голосних. Таким чином, випускники ЗСО демонструють некоректне фонетичне оформлення потоку мовлення, яке грунтується на деформованих фонетичних навичках і сприймається як ненормативне.

Таким рівнем фонетичної підготовки випускників ЗСО ми завдячуємо гіпертрофованому розумінню вчителями німецької мови принципу апроксимації. Важливість фонетичного аспекту ніколи не ставилась вчителями під сумнів, проте на уроках німецької мови йому не приділяється достатньо уваги. За результатами опитування $(2007,2008)$, в якому взяли участь студенти семи українських 3ВО, 37\% (2007) та 21\% (2008) респондентів зазначили, що на уроках німецької мови над вимовою не працювали взагалі. Час від часу над вимовою працювали $40 \%$ (2007) і відповідно 51\% у 2008 (Гутник, 2017).

Підсумки опитування 87-ми студентів Київського національного лінгвістичного університету (КНЛУ) у 2013-2017 р.р. свідчать про те, що ситуація в цій царині не змінилася на краще. Сучасні технічні можливості, мобільність учнів за програмами обміну й розуміння необхідності володіння IM мали б сприяти покращенню ситуації. Всупереч очікуванням кількість “фонетично слабких" випускників ЗСО збільшилась (див. табл. 1).

Таблиця 1

Результати опитування (2013-2017 р.p.)

\begin{tabular}{|c|c|c|c|}
\hline \multicolumn{4}{|c|}{ Чи приділялась увага фонетиці, а саме формуванню вимовно-інтонаційних навичок під } \\
\hline \multicolumn{4}{|c|}{ час вивчення вами німецької мови в школі? } \\
\hline Рiк & Так & $\mu i$ & Інодi \\
\hline 2013 & $25 \%$ & $75 \%$ & $0 \%$ \\
\hline 2014 & $23,8 \%$ & $57,1 \%$ & $19 \%$ \\
\hline 2015 & $0 \%$ & $55,5 \%$ & $44,4 \%$ \\
\hline 2016 & $4 \%$ & $56 \%$ & $40 \%$ \\
\hline 2017 & $21,4 \%$ & $53,5 \%$ & $25 \%$ \\
\hline У середньому & $14,8 \%$ & $59,4 \%$ & $25,6 \%$ \\
\hline
\end{tabular}

Як видно 3 табл. 1, 59,4\% учнів українських ЗСО зовсім не працювали над вимовою під час вивчення німецької мови. Показники унаочнюють тенденцію недбалого ставлення вчителів до фонетичного аспекту.

На запитання "Як ви оцінюєте свою вимову перед початком вступного корективного курсу?” у 2007-2008 p.p. ми отримали такі відповіді: 2\% опитаних оцінили свою вимову на “дуже добре”, 11\% на “добре”, 37\% як “задовільну” і 50\% як “незадовільну” (Гутник, 2017). Як видно 3 табл. 2, динаміка протягом 2013-2017 p.p. майже не зазнала змін.

Таблиця 2

Результати опитування (2013-2017 р.p.)

\begin{tabular}{|c|c|c|c|c|}
\hline \multicolumn{4}{|c|}{ Як ви оцінюєте свою вимову перед початком вступного корективного курсу?” } \\
\hline Рік & "дуже добре" & “добре” & "задовільно" & "погано” \\
\hline 2013 & $0 \%$ & $0 \%$ & $50 \%$ & $50 \%$ \\
\hline 2014 & $25 \%$ & $28,5 \%$ & $47,6 \%$ & $19 \%$ \\
\hline 2015 & $0 \%$ & $11,1 \%$ & $33,3 \%$ & $55,5 \%$ \\
\hline 2016 & $0 \%$ & $12 \%$ & $36 \%$ & $52 \%$ \\
\hline 2017 & $7,1 \%$ & $25 \%$ & $25 \%$ & $42,8 \%$ \\
\hline У середньому & $6,4 \%$ & $15,3 \%$ & $38,3 \%$ & $43,8 \%$ \\
\hline
\end{tabular}

Усе це спричинює формування усталених ненормативних навичок, які демонструються вже на першому занятті у ЗВО і “переслідують” студента тривалий час. У такому разі слід говорити про фонетичні помилки, причини їх виникнення, корекцію й профілактику. 
Гутник В. М. Причини, профілактика й корекція фонетичних помилок у вступному корективному курсі

Поняття “помилка” тлумачиться науковцями найчастіше як відхилення від норми. К. Клеппін розуміє помилку як те, що суперечить загальноприйнятому - правильному - або ж відступає від нього (Kleppin, 1998). Г. Ліст називає помилку індикатором або вікном, через яке ми можемо безпосередньо спостерігати за процесом навчання (List, 1980). Студенти визначають помилку як неправильну відповідь (57,5\%), як ознаку незасвоєності матеріалу $(18,1 \%)$, як спосіб покращення учіння (9,0\%) (Результати опитування студентів КНЛУ, 2018).

Фонетичні помилки належать до найскладніших, адже учень чи студент не в змозі виправити їх самостійно. Викладач часто змушений декілька разів повторити помилку задля того, щоб студент міг iї розпізнати і виправити (Kleppin, 1998). 81,8\% студентів розуміють фонетичну помилку як “неправильну вимову звуків й інтонації”, “незнання правил фонетичної вимови”, “фонетичну некоректність”, “фонетично неправильно оформлене висловлювання” (Результати опитування студентів КНЛУ, 2018). Фонетична помилка має свою специфіку. Ми визначаємо іiі як відхилення від фонетичної норми (як на сегментному, так і на супрасегментному рівнях), що може спричинити порушення процесу комунікації.

При визначенні причин помилок науковці вказують насамперед на міжмовну і внутрішньомовну інтерференцію, роль комунікаційних і навчальних стратегій, а також соціальних й індивідуальних особливостей (Kleppin, 1998). Першопричину фонетичних помилок ми вбачаємо в дї фільтра рідної мови (Bausch, 2007; Storch, 2001). Інші автори послуговуються термінами фонологічне сито (Trubezkoy, 1989), просодичне сито (Валігура, 2010), сітка (Cauneau, 1992), шаблон (Hirschfeld, 1992). А. Томатіс ввів поняття лінгвістичного коду, який може загальмувати процес оволодіння IM (Tomatis, 1991). В той час як більшість науковців вважає, що в основі механізму фільтру рідної мови лежать особливості артикуляційної бази рідної мови, А. Томатіс вказує на різницю у звукових частотах різних мов (Tomatis, 1991; 2003). Дослідивши фонетичні зразки, він встановив, що кожна мова реалізується у певному спектрі частот: німецька 125-3000 Hz, англійська 3000-12000 Hz, російська 125-8000 Hz тощо (Tomatis, 1991; 2003). Учений стверджує, що для кожної людини існують частоти, до яких вона є відносно нечутливою (глухою). Також він описує таку особливість звукосприйняття, як повний акустичний спротив (akustische Impedanz), що спричинюється навколишнім середовищем, в якому функціонує та чи інша мова (Tomatis, 1991; 2003).

Це дає підстави зробити висновок, що дія фільтру рідної мови ускладнює як сприйняття, так і відтворення усного мовлення, оскільки фільтр пропускає лише ті форми, які особа звикла чути й розуміти (Hirschfeld, 1992; Selinker, 1992). Внаслідок цього учні ЗСО, а з часом студенти ЗВО неспроможні декодувати “почуту” інформацію; це означає, що не вся презентована звукова інформація розпізнається. Лише адекватно декодована звукова одиниця може бути нормативно відтворена: 3 цієї причини учні / студенти припускаються помилок, які вони не можуть розпізнати й ідентифікувати як такі.

Слід звернути увагу на те, що помилки, які не коригуються і не виправляються на початковому ступені навчання й вивчення IM, з часом дуже важко піддаються корекції або ж взагалі не можуть бути виправленими з причини максимальної автоматизації (Dieling, 1991). Вони фосилізуються. Явище фосилізації описано в роботах Х.-Ц. Хонг (Hong, 2004), Х.-В. Хунеке (Huneke, 2002), К. Накума (Nakuma, 2006), Л. Селінкер (Selinker, 1972; 1992), В. Кочубей (Кочубей, 2006).

Під фосилізацією розуміють так зване “скам’яніння” форм, що не відповідають мовній нормі; свого роду “застій”, в якому зберігаються особливості “міжмови” (Interlanguages) всупереч інтенсивному навчанню чи тривалому перебуванню в країні виучуваної мови (Edmondson, House, 2000). Фосилізація спричинює стан у процесі оволодіння другою IM, в якому той, хто вивчає IM, залишається тривалий час на тому самому рівні, де не відмічаються ні прогрес, ні регрес (Kniffka, Siebert-Ott, 2007). 
Якщо фонетичні помилки не виявляються і не коригуються вчасно, ті, хто вивчають IM, створюють у своїй “мовній спільноті” (Huneke, Steinig, 2002) норму, яка зазнає значного впливу їхньої рідної мови. У такій групі (Lernersprachgemeinschaft) мовці орієнтуються лише на вимову одне одного і напрацьовують “Unterrichts-Pidgin" - спотворений варіант IM, який нормативним вважають лише члени цієї групи. 3 цієї причини Х.-В. Хунеке й В. Штайніг вважають доцільним i необхідним уже на початковому ступені навчання й вивчення IM забезпечити в процесі навчання нормативність вимови. Це бажано робити в рамках фонетичного курсу (Huneke, Steinig, 2002). У мовному ЗВО він розпочинається традиційно з першого заняття і має на меті формування ІКК з акцентом на ії фонетичній складовій, а також корекцію ненормативних фосилізованих фонетичних навичок, сформованих під час навчання у ЗСО.

Сучасний вступний корективний курс має відповідати вимогам, викладеним у Європейських рекомендаціях (Ніколаєва, 2003) та Типовій програмі (Borisko, Gutnik, Klimentjewa, Ignatenko, Ivanenko, Lasarenko, 2004). Насамперед він повинен відображати актуальне розуміння комплексності - містити вправи і завдання для формування усіх мовленнєвих компетентнотсей; за способом організації сучасний ВКК має бути призначеним для інтегрованого чи безаспектного навчання й вивчення IM; зміст сучасного курсу й дібраний навчальний матеріал мають реалізовуватись у відповідних мінімумах - тематичному, функціональному й мовному з урахуванням існуючих між ними природних кореляцій; сучасний ВКК має грунтуватись на положеннях комунікативного підходу - бути комунікативно спрямованим; неодмінною вимогою до змісту ВКК є його спрямованість на формування навчальної автономії студента; сучасний ВКК повинен бути професійно орієнтованим (Гутник, 2017).

Ми розуміємо ВКК як складний багатовекторний процес, пріоритетом якого слід вважати корекцію помилок. Інакше кажучи, процес навчання має супроводжуватись своєчасним коригуванням помилок. На перший план у цьому процесі виступають індивідуальні психологічні особливості учнів / студентів, які мають ураховуватись під час виправлення помилок.

Як показує багаторічний досвід організації й проведення ВКК, студенти вже на перших заняттях з німецької мови виявляють специфічне ставлення до помилок та їх корекції - у них виникає страх перед помилкою. Це спонукало нас провести опитування, результати якого показали, що виправлення помилок під час навчання у ЗСО провокувало прояв в учнів спектра негативних емоцій: у 48,4\% - пригнічення, у $36,3 \%$ - байдужість, у 12,1\% - роздратування до вчителя, або ж до самого себе (КНЛУ, 2018). Думки щодо форми й способу виправлення помилок на шкільних уроках розподілились так: неприйнятними їх вважають 51,5\%, прийнятними - 39,3\%; 9,2\% з відповіддю не визначились. Внаслідок такого негативного емоційного досвіду, здобутого під час навчання у $3 \mathrm{CO}$, першокурсники під час виправлення помилки відчувають дискомфорт, який вимірюється в середньому п'ятьма балами за десятибальною шкалою. I навіть якщо вони самі помічають свою помилку і виправляють iii самостійно, вони також відчувають дискомфорт, який дорівнює п’яти балам.

3 метою докладнішого вивчення особливостей психологічного стану першокурсників ми звернулись до праць психологів. Згідно з дослідженням Т. В. Завадської (Завадська, 2011) стосовно показників нейродинаміки вчителів різної кваліфікації (у дослідженні взяли участь учителі IM I-II категорій і вищої кваліфікації) у більшості вчителів всіх трьох груп виявлено низький рівень урівноваженості. Ймовірним стилем реагування вчителя на помилку учня в такому разі може бути неконтрольована афективна реакція.

За тестуванням властивості “активність-пасивність” у більшості вчителів всіх трьох категорій професіоналізму виявлено пасивність або іï середній прояв, коли активність нівелюється пасивністю. На противагу реакції вираженої емоційності проявляється тенденція до пасивного стилю взаємодії в межах освітнього процесу, що унеможливлює своєчасне й адекватне коригування фонетичного оформлення мовленнєвого потоку. 
Гутник В. М. Причини, профілактика й корекція фонетичних помилок у вступному корективному курсі

У ході цієї наукової розвідки з'ясувалось, що більшості вчителів I-II категорій професіоналізму притаманна ригідність (відповідно 52,2\% і 47,6\%), яка є показником консерватизму, певного догматизму, навіть обмеження саморозвитку і перешкоджає професійному зростанню й особистісному розвитку. Ригідність у виправленні помилок може проявлятись у безальтернативності, зацикленості на єдино правильному варіанті відповіді, яка зазвичай має збігатися з думкою вчителя. Нетерпимість до висловлення іншої думки є одним із проявів домінантності як риси характеру: вона унеможливлює адекватну й ефективну “суб'єкт” “суб'єктну” взаємодію і заміщає ії суб'єкт”-“об’ єктною” (учень сприймається як об'єкт) та формує тенденцію до авторитарного стилю керівництва. Такий учитель зафіксовує перевагу свого становища задля подолання спротиву учня, примушуючи його засвоїти установки вчителя (Киршбаум, Еремеева, 2005). I якщо дитина пасивно підпорядковується вимогам дорослого, вона у кращому разі буде відтворювати засвоєне, але у неї не з'явиться жодної нової потреби і не відбуватиметься жодного суттєвого просування у психічному розвитку (Божович, 2008).

Усі описані особливості дають підставу трактувати страх першокурсників перед помилкою як зафіксовану модель поведінки, ймовірно сформовану під час навчання у ЗСО.

Усе викладене вище, зокрема аргументи, які свідчать про недбале ставлення вчителів IM до фонетичного аспекта мовлення, нехтування психологічними особливостями навчальної поведінки учнів збігається на початковому ступені навчання й вивчення IM з адаптаційним періодом - усе це значно ускладнює процес навчання, потребуючи додаткових затрат часу й зусиль викладача IM й особливої методики формування IКК та її складових.

Ми уклали комунікативний вступний корективний курс, який відповідає Програмним вимогам та сучасному баченню. Зміст ВКК було дібрано, організовано й порціоновано в такий спосіб, щоб викликати інтерес до навчального матеріалу, підвищити мотивацію, забезпечити “позитивність” сприйняття і сформувати адекватне ставлення до помилки як до діагностичного маркера, який допомагає студентові визначити, що він знає і може на кожному конкретному етапі роботи над IM, і фонетичним аспектом зокрема, які прогалини він має у своїх знаннях і яких заходів слід ужити, щоб виправити ситуацію. Виявлена помилка має допомогти студенту критично оцінити свої успіхи й невдачі, а також реорганізувати самостійну роботу.

У змісті ВКК цьому сприяє створення цілісної сюжетної лінії - “скайп” - історія про першокурсників, їхні життєві обставини, інтереси, яка максимально відтворює реальність студентського життя.

Варто зауважити, що при укладанні навчальних текстів для аудіювання й читання вголос ми керувались таким критерієм, як “фонетична насиченість” (авторський робочий термін), під яким розуміємо частоту вживання виучуваного звука / фонетичного явища. Ми розрізняємо “фонетичну насиченість” лексичних одиниць - обов’ язкова присутність звука / фонетичного явища в слові - та “фонетичну насиченість” навчального тексту, який укладено з використанням фонетично насичених лексичних одиниць. Середній показник “фонетичної насиченості” навчальних текстів у ВКК становить не менше $15 \%$.

Задля деавтоматизації деформованих фосилізованих навичок, відповідної корекції наявних і профілактики можливих помилок роботу над текстовим матеріалом і вправами організовано в такий спосіб, що студенти формулюють фонетичні правила самостійно (див. приклад 1).

Приклад 1. Мета: самостійне виведення фонетичних знань

Додаткова мета: формування орфографічних навичок написання фонетичних термінів.

Тип вправи: репродуктивна, некомунікативна, поліфункціональна.

Вид вправи: заповнення пропусків за смислом.

Завдання:

a. Lesen Sie die Regel still. Nennen Sie die Termini, die einzusetzen sind. Übersetzen Sie diese in die Muttersprache. 
b. Ergänzen Sie die Regel.

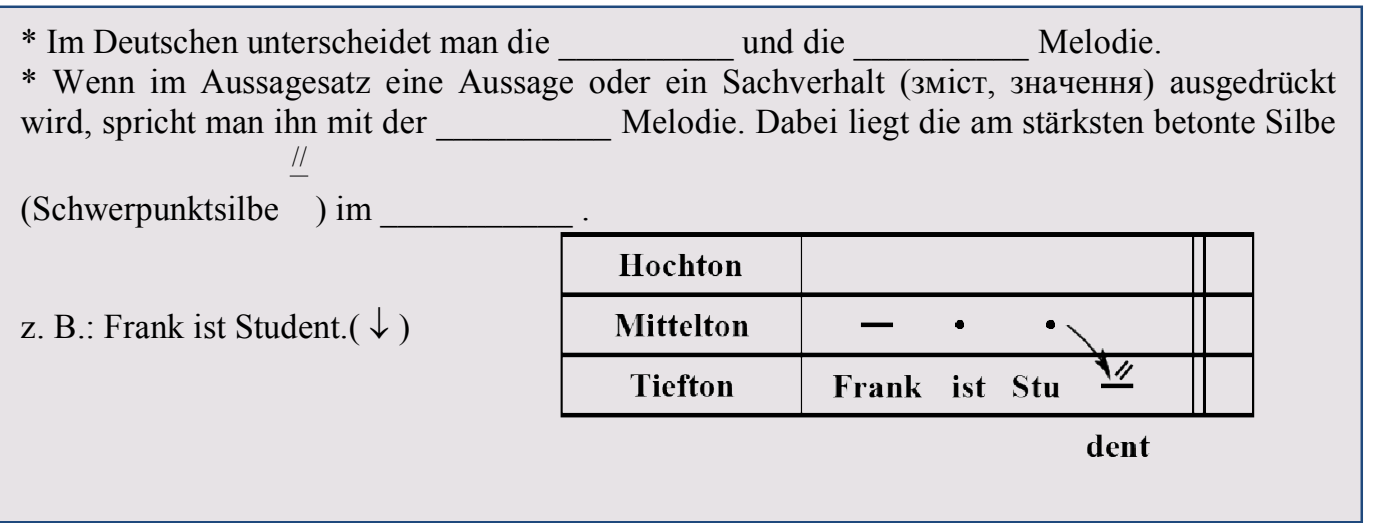

У цьому разі студент вважає правило “власним продуктом”, який є для нього максимально зрозумілим і не створює додаткових труднощів. Це допомагає позбутися помилок, спричинених відсутністю фонетичних знань, і надалі уникати подібних.

Для ефективної корекції наявних і профілактики можливих помилок вважаємо доцільним застосування розроблених нами $n$ 'яти- (“Fünf-Schritte-Methode") і трикрокових комплексних вправ, які грунтуються на теорії I. О. Зимньої про формування еталонних зон (див. приклад 2).

Приклад 2. Мета: формування інтонаційних навичок у читанні вголос - інтонаційного слуху.

Тип вправи: репродуктивна, некомунікативна, комплексна, п'ятикрокова.

Вид вправи: визначення на слух типів мелодики у реченнях зв'язного тексту та їх реалізація у різних режимах.

Завдання:

Schritt 1. Bert hat einen Freund. Er heißt Frank. Hören Sie Berts Erzählung über seinen Freund und zeigen Sie mit der Hand die Melodie.

\section{Das macht Spaß}

Seit September ist Frank Student. Er studiert sein Lieblingsfach, die englische Sprache. Da muss er viel und intensiv arbeiten. Unermüdlich übt er die richtige Aussprache. Gern hört er Texte im Original. Beim Hören zeigt er mit der Hand die Melodie. Er brummt Texte nach. Das ist lustig. Das macht ihm Freude. Er flüstert Sätze nach. Er spricht sie mit. Er liest Texte halblaut. Er liest sie vor. Frank macht Fortschritte. In fünf Schritten übt er die akzentfreie Aussprache. Das macht ihm Spaß.

Schritt 2. Hören Sie die Erzählung wieder und artikulieren Sie die Sätze stimmlos. Zeigen Sie dabei die Melodie.

Schritt 3. Brummen Sie Sätze und zeigen Sie auch die Melodie.

Schritt 4. Flüstern Sie die Sätze und zeigen Sie dabei die Melodie.

Schritt 5. Sprechen Sie die Sätze halblaut nach und zeigen Sie die Melodie.

При опрацюванні будь-якого фонетичного тексту вважаємо принципово важливим проходження всіх ступенів формування звукового еталону й дотримання їх послідовності, оскільки нехтування одним із них унеможливить його успішне формування; про це свідчить нездатність студентів чути помилки одногрупників, а також і свої власні, як на початку ВКК, так і після його завершення. Застосування п'яти- й трикрокових вправ рекомендовано як під час аудиторних занять, так і у самостійній роботі. Викладач має навчити студентів працювати за цими прийомами й акцентувати увагу на необхідності виконання передбачених кроків і дотримання їхньої послідовності під час самостійної роботи.

Як три-, так і п'ятикрокові вправи розпочинаються з прослуховування, не активуючи механізми артикуляції. Наступним кроком є формування навичок тонічної / беззвучної 
Гутник В. М. Причини, профілактика й корекція фонетичних помилок у вступному корективному курсі

артикуляції. Після цього мелодичний контур фрази відтворюється “гудінням”, що сприяє формуванню навичок інтонування. Далі пропонується читання пошепки. П’ятим останнім кроком є читання фраз напівголосно, разом з диктором. При цьому студентам пропонується супроводжувати кожну фразу жестами для відтворення мелодичного контуру.

П’ятикрокові вправи призначено для формування різної диференційної чутливості й нових слухових еталонів (Зимняя, 1985), які сприяють деавтоматизації ненормативних фосилізованих фонетичних навичок, сформованих під час навчання й вивчення IM у ЗСО.

Трикрокові вправи мають на меті формування навичок тонічної артикуляції, читання пошепки й читання разом $з$ диктором; їх призначено здебільшого для формування диференційної чутливості до одиниць сегментного рівня, адже беззвучна артикуляція спричинює максимальне напруження голосових зв'язок, уповільнення темпу мовлення, отже - й чіткішу артикуляцію. При цьому зауважимо, що як п’яти-, так і трикрокові вправи сприяють формуванню диференційної чутливості до фонетичних одиниць обох рівнів і нормативних слухових еталонів.

Грунтовне вивчення процесу формування ФК у комунікативному ВКК, його психолінгвістичних і дидактичних особливостей дало змогу розробити підсистему вправ, яка містить шість груп вправ: для формування ФК в аудіюванні, читанні вголос, говорінні, для набуття фонетичних знань, розвитку фонетичної сенсибілізації й формування фонетичної усвідомленості (Гутник, 2017). Усі вправи та їхні комплекси призначено для формування ФК, успішність перебігу якого залежить від своєчасної й ефективної роботи над помилками.

Висновки і перспективи подальших розвідок.

Розроблена нами підсистема вправ для формування ФК у комунікативному ВКК може служити у подальших дослідженнях особливостей формування іншомовної комунікативної компетенції в цілому і фонетичної компетенції зокрема.

Укладені нами вправи можуть бути враховані при організації та проведенні вступних корективних курсів, а також у ході подальшого вдосконалення фонетичної компетенції як під час аудиторних занять, так і в самостійній роботі. Вправи можуть бути використані безпосередньо в процесі навчання, а також як допоміжний матеріал для створення додаткових комплексів вправ чи фонетичних курсів.

\section{ЛІТЕРАТУРА}

Божович, Л. И. (2008). Личность и ее формирование в детском возрасте. Санкт-Петербург, Российская Федерация: СПб.

Валігура, О. Р. (2010). Лінгвокогнітивні і комунікативні основи фонетичної інтерференції (експериментально-фонетичне дослідження англійського мовлення українців) (Докторська дисертація). Київський національний лінгвістичний університет, Київ, Україна.

Гутник, В. М. (2017). Формування фонетичної компетенції у майбутніх учителів німецької мови у комунікативному вступному корективному курсі (Автореферат кандидатської дисертації). Київський національний лінгвістичний університет, Київ, Україна.

Гутник, В. М. (2017). Формування фонетичної компетенції у майбутніх учителів німецької мови у комунікативному вступному корективному курсі (Кандидатська дисертація). Київський національний лінгвістичний університет, Київ, Україна.

Завадська, Т. В. (2011). Показники нейродинаміки вчителів різної кваліфікації. Актуальні проблеми психології, 5 (11), 5 - 60.

Зимняя, И. А. (1985). Психологические аспекты обучения говорению на иностранном языке. Москва, Российская Федерация: Просвещение.

Іноземні мови. Навчальні програми для 1 - 4 класів загальноосвітніх навчальних закладів та спеціалізованих шкіл (ОНОВЛЕНО). Джерело доступу: http://mon.gov.ua/activity/education/ zagalna-serednya/navchalni-programy.html 
Киршбаум, Э., Еремеева, А. (2005). Психологическая защита. Питер, Российская Федерация: Смысл.

Ніколаєва, С. Ю. (Наук. ред. укр. вид.). (2003). Загальноєвропейські Рекомендаииї з мовної освіти: вивчення, викладання, оиінювання. Київ, Україна: Ленвіт.

Bausch, K.-R., Christ, H., Krumm, H.-J. ( 2007). Handbuch Fremdsprachenunterricht. Tübingen und Basel, Deutschland: A. Francke Verlag.

Borisko, N., Gutnik, W., Klimentjewa, M., Ignatenko, T., Ivanenko, S., Lasarenko, O.) 2004. Curriculum für den sprachpraktischen Deutschunterricht an pädagogischen Fakultäten der Universitäten und pädagogischen Hochschulen. Київ, Україна: Ленвіт.

Cauneau, I. (1992). Hören - Brummen - Sprechen. Hören und Ausspracheschulung. Fremdsprache Deutsch. Heft 7. Berlin, Deutschland: Erich Schmidt Verlag.

Dieling, H. (1991). Nicht bagatellisieren. Phonetische Fehler im Fremdsprachenunterricht. Deutsch als Fremdsprache. Heft 2. München / Berlin, Deutschland: Langenscheidt.

Dieling, H., Hirschfeld, U. (2000). Phonetik lehren und lernen. Fernstudieneinheit 21. Kassel-MünchenTübingen, Deutschland: Langenscheidt.

Edmondson, W., House, J. (2000). Einführung in die Sprachlehrforschung. 2., überarb. Aufl. Tübingen, Basel: Francke.

Hirschfeld, U. (1992). Wer nicht hören will ... Phonetik und verstehendes Hören. Fremdsprache Deutsch. - Heft 7. Berlin, Deutschland: Erich Schmidt Verlag.

Huneke, H.-W., Steinig, W. (2002). Deutsch als Fremdsprache: eine Einführung. 3., überarb. und erw. Aufl. Berlin, Deutschland: Erich Schmidt.

Kleppin, K. (1998). Fehler und Fehlerkorrektur. München, Deutschland: Druckhaus Langenscheidt.

Kniffka, G., Siebert-Ott, G. (2007). Deutsch als Zweitsprache. Lehren und Lernen. Padeborn, Deutschland: Ferdinand Schöningh.

List, G. (1980). Fehler beim Verstehen. In D. Cherubim (Hrsg.), Fehlerlinguistik (S. 251 - 265). Tübingen, Deutschland: Max Niemeyer Verlag.

Selinker, L. (1992). Rediscovering Interlanguage. London and New York: Longman.

Storch, G. Deutsch als Fremdsprache (2001). Eine Didaktik. Theoretische Grundlagen und praktische Unterrichtsgestaltung. München, Deutschland: Fink.

Tomatis, A. (1991). Nous sommes tous nés polyglottes. France: Fixot.

Tomatis, A. (2003). Das Ohr und das Leben. Düsseldorf, Deutschland: Walter Verlag.

Trubezkoy, N. S. (1989). Grundzüge der Phonologie. 7. Aufl. Göttingen, Deutschland: Vandenhoeck \& Ruprecht.

\section{REFERENCES}

Bozhovich, L. I. (2008). Lichnost' i ee formirovanie v detskom vozraste. Sankt-Peterburg, Rossijskaya Federaciya: $\mathrm{SPb}$.

Valigura, O. R. (2010). Lingvokognitivni i komunikativni osnovi fonetichnoï interferenciï (eksperimental'no-fonetichne doslidzhennya anglijs'kogo movlennya ukraïnciv) (Doktors'ka disertaciya). Kiïvs'kij nacional'nij lingvistichnij universitet, Kiïv, Ukraïna.

Gutnik, V. M. (2017). Formuvannya fonetichnoï kompetenciï u majbutnih uchiteliv nimec'koï movi u komunikativnomu vstupnomu korektivnomu kursi (Avtoreferat kandidats'koï disertaciï). Kï̈vs'kij nacional'nij lingvistichnij universitet, Kiïv, Ukraïna.

Gutnik, V. M. (2017). Formuvannya fonetichnoï kompetenciï u majbutnih uchiteliv nimec'koï movi u komunikativnomu vstupnomu korektivnomu kursi (Kandidats'ka disertaciya). Kï̈vs'kij nacional'nij lingvistichnij universitet, Kiïv, Ukraïna.

Zavads'ka, T. V. (2011). Pokazniki nejrodinamiki vchiteliv riznoï kvalifikaciï. Aktual'ni problemi psihologiï, 5 (11), 5-60. 
Zimnyaya, I. A. (1985). Psihologicheskie aspekty obucheniya govoreniyu na inostrannom yazyke. Moskva, Rossijskaya Federaciya: Prosveshchenie.

Inozemni movi. Navchal'ni programi dlya $1-4$ klasiv zagal'noosvitnih navchal'nih zakladiv ta specializovanih shkil (ONOVLENO). Dzherelo dostupu: http://mon.gov.ua/activity/education/ zagalna-serednya/navchalni-programy.html

Kirshbaum, E., Eremeeva, A. (2005). Psihologicheskaya zashchita. Piter, Rossijskaya Federaciya: Smysl.

Nikola€va, S. YU. (Naukovij redaktor ukraïns'kogo vidannya). (2003). Zagal'noєvropejs'ki Rekomendaciï z movnoï osviti: vivchennya, vikladannya, ocinyuvannya. Kiïv, Ukraïna: Lenvit.

Bausch, K.-R., Christ, H., Krumm, H.-J. ( 2007). Handbuch Fremdsprachenunterricht. Tübingen und Basel, Deutschland: A. Francke Verlag.

Borisko, N., Gutnik, W., Klimentjewa, M., Ignatenko, T., Ivanenko, S., Lasarenko, O.) 2004. Curriculum für den sprachpraktischen Deutschunterricht an pädagogischen Fakultäten der Universitäten und pädagogischen Hochschulen. Kyiv, Ukraina: Lenvit.

Cauneau, I. (1992). Hören - Brummen - Sprechen. Hören und Ausspracheschulung. Fremdsprache Deutsch. Heft 7. Berlin, Deutschland: Erich Schmidt Verlag.

Dieling, H. (1991). Nicht bagatellisieren. Phonetische Fehler im Fremdsprachenunterricht. Deutsch als Fremdsprache. Heft 2. München / Berlin, Deutschland: Langenscheidt.

Dieling, H., Hirschfeld, U. (2000). Phonetik lehren und lernen. Fernstudieneinheit 21. Kassel-MünchenTübingen, Deutschland: Langenscheidt.

Edmondson, W., House, J. (2000). Einführung in die Sprachlehrforschung. 2., überarb. Aufl. Tübingen, Basel: Francke.

Hirschfeld, U. (1992). Wer nicht hören will ... Phonetik und verstehendes Hören. Fremdsprache Deutsch. - Heft 7. Berlin, Deutschland: Erich Schmidt Verlag.

Huneke, H.-W., Steinig, W. (2002). Deutsch als Fremdsprache: eine Einführung. 3., überarb. und erw. Aufl. Berlin, Deutschland: Erich Schmidt.

Kleppin, K. (1998). Fehler und Fehlerkorrektur. München, Deutschland: Druckhaus Langenscheidt.

Kniffka, G., Siebert-Ott, G. (2007). Deutsch als Zweitsprache. Lehren und Lernen. Padeborn, Deutschland: Ferdinand Schöningh.

List, G. (1980). Fehler beim Verstehen. In D. Cherubim (Hrsg.), Fehlerlinguistik (S. 251 - 265). Tübingen, Deutschland: Max Niemeyer Verlag.

Selinker, L. (1992). Rediscovering Interlanguage. London and New York: Longman.

Storch, G. Deutsch als Fremdsprache (2001). Eine Didaktik. Theoretische Grundlagen und praktische Unterrichtsgestaltung. München, Deutschland: Fink.

Tomatis, A. (1991). Nous sommes tous nés polyglottes. France: Fixot.

Tomatis, A. (2003). Das Ohr und das Leben. Düsseldorf, Deutschland: Walter Verlag.

Trubezkoy, N. S. (1989). Grundzüge der Phonologie. 7. Aufl. Göttingen, Deutschland: Vandenhoeck \& Ruprecht. 